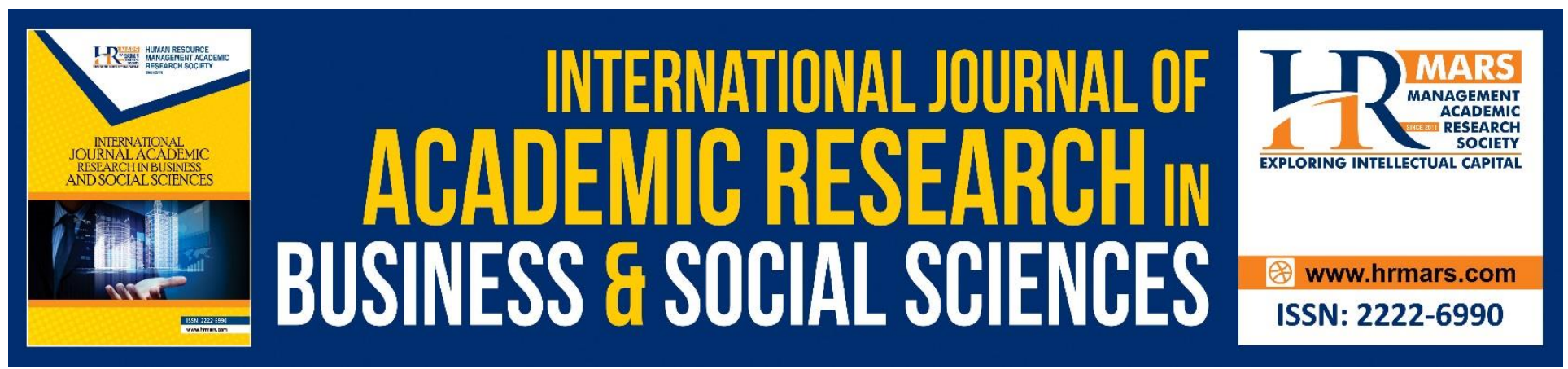

\title{
Analysis of Sustainability Assessment Tools (SATs) for Higher Education Institutions (HEls)
}

\section{Mohd Zamri Husaini, Ahmad Jusoh \& Mohamad Shah Kassim}

To Link this Article: http://dx.doi.org/10.6007/IJARBSS/v8-i8/4612

DOI: $\quad 10.6007 /$ IJARBSS/v8-i8/4612

Received: 16 June 2018, Revised: 29 July 2018, Accepted: 30 July 2018

Published Online: 13 August 2018

In-Text Citation: (Husaini, Jusoh, \& Kassim, 2018)

To Cite this Article: Husaini, M. Z., Jusoh, A., \& Kassim, M. S. (2018). Analysis of Sustainability Assessment Tools (SATs) for Higher Education Institutions (HEIs). International Journal of Academic Research in Business and Social Sciences, 8(8), 558-571.

\section{Copyright: (C) 2018 The Author(s)}

Published by Human Resource Management Academic Research Society (www.hrmars.com)

This article is published under the Creative Commons Attribution (CC BY 4.0) license. Anyone may reproduce, distribute, translate and create derivative works of this article (for both commercial and non-commercial purposes), subject to full attribution to the original publication and authors. The full terms of this license may be seen at: $\underline{\text { http://creativecommons.org/licences/by/4.0/legalcode }}$

Vol. 8, No. 8, August 2018, Pg. 558 - 571

Full Terms \& Conditions of access and use can be found at http://hrmars.com/index.php/pages/detail/publication-ethics 


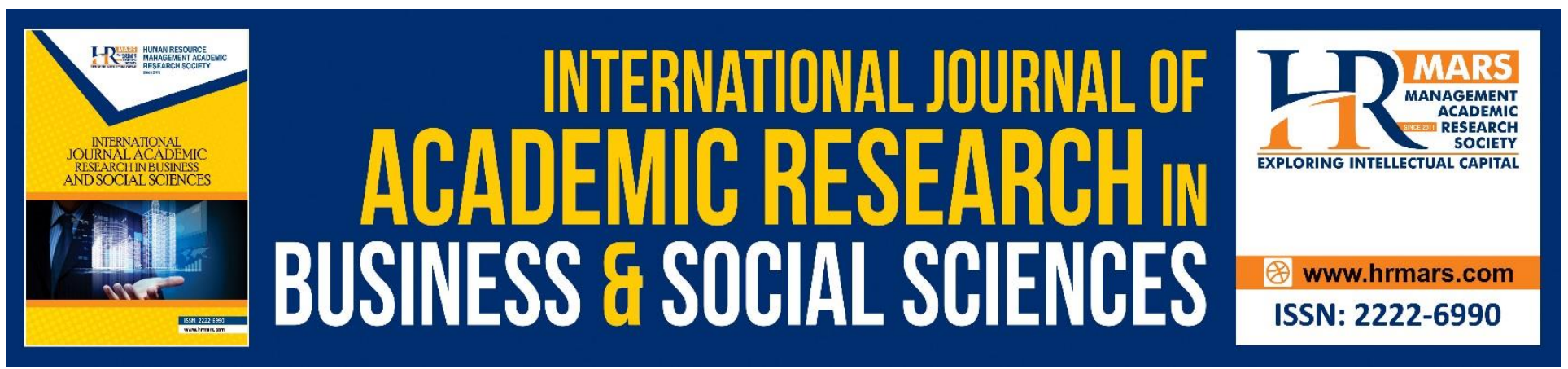

\title{
Analysis of Sustainability Assessment Tools (SATs) for Higher Education Institutions (HEls)
}

\author{
Mohd Zamri Husaini, Ahmad Jusoh \& Mohamad Shah Kassim \\ Azman Hashim International Business School (AHIBS), Universiti Teknologi Malaysia, 81310 Johor \\ Bahru, Johor, Malaysia.
}

\begin{abstract}
During the last few years, there are many sustainability assessment tools (SATs) were developed and introduced to higher education institutions (HEIs) that functions to guide and assess the commitment of HEls to implement sustainability. The aim of this study is to review and analysis four existing SATs namely as Sustainability Tracking, Assessment and Rating System (STARS), Campus Sustainability Assessment Framework (CSAF), UI GreenMetric Ranking and Sustainable Assessment Questionnaire (SAQ) which have been embedded and used as their sustainability guidance by many institutions in the world. The analysis is conducted by reviewing the indicators contained within the SATs and then the indicators will be gathered according 1) to the aspect of sustainability; environment, social and economics and 2) between the key elements of each SAT. Result found that there were a significant imbalanced proportion of indicators between the aspect of sustainability and between the key elements of sustainability among the sustainability assessment tools.
\end{abstract}

Keywords: Sustainability, Sustainable Development, Sustainability Assessment Tools, Higher Education, Sustainability Indicators.

\section{Introduction}

In 1975, for the first time the UNESCO-UNEP International Environmental Education Programme had introduced about the concept of sustainability in the education and international level. This programme was managed and organized by the United National Educational, Scientific and Cultural Organization (UNESCO) and United Nation Environmental Programme (UNEP) (UNESCO, 1984). The issues of sustainability especially in higher education has been discussed through many international declarations such as Tbilisi declaration in 1977, Tallories decalaration in 1990, Haliffax declaration in 1991 and many more.

Since the development of the declarations in 1990s many sustainability assessment tools (SATs) have been developed and introduced to assess the level of sustainability initiatives in HEls with different themes and indicators and methodology of assessments. Nixon (2002) highlighted that there are three main objectives of developing SATs that includes [i]identifying areas and [ii]developing strategies for campus to improve their sustainability performances and [iii]to foster 
INTERNATIONAL JOURNAL OF ACADEMIC RESEARCH IN BUSINESS AND SOCIAL SCIENCES

Vol. 8, No. 8, August 2018, E-ISSN: 2222-6990 @ 2018 HRMARS

sustainability culture to implement sustainability. The development of SATs also should identify the important issues, can be measured and comparable, comprehensibility and contain more themes other than eco-efficiency (Shirberg, 2002).

There are several issues involving sustainability assessment tools (SATs) as highlighted by several scholars. Shriberg (2002) who analysed 11 cross institutional sustainability assessment tools (SATs) found that the SATs are greatly vary in terms of purpose, scope, function and development. The study also found that most SATs emphasized more on environmental or eco-efficiency factors such as decreasing of energy, water and other materials input rather on the need of functional areas.

Additionally Yarime and Tanaka (2012) also studied 16 tools of SATs and found that the overall percentage of the tool indicators are $44 \%$ in operation, $39 \%$ in governance and $8 \%$ in education. Besides that, there are several other key elements of sustainability found from the study such as curriculum, local community and research projects. Furthermore Fischer et. al (2015) studied 12 sustainability tools and found that most of the tools contained $67 \%$ in operation elements and $18 \%$ in education elements. The study highlights that the highest numbers of indicators from the 12 tools are from the physical resources and institutionalization then followed by education, curriculum, human resource and research.

Apart from that, Berzosa et. al (2017) compares the findings of four studies related to SATs analysis by Cole (2003), Shirberg (2012), Yarime and Tanaka (2012) and Fischer et. al (2015). Based on their analysis, it can be concluded that most of SATs contains different criterias and elements of sustainability. Berzosa et. al (2017) concludes that, it is important for HEls to understand the concept of sustainability and more studies should be done to analyse the sustainability assessment tools before implementing them within the campus.

The element of sustainability should fulfill the aspects of environment, economics and social (Elkington, 2004) and focusing on a balance of the three aspects (Brundtland, 1987). The word sustainability is famously defined as "development that meets the needs of the present without compromising the ability of future generations to meet their needs" (Brundtland, 1987). Lozano (2009) defines sustainability as a holistic and interconnected phenomenon of economics, environmental and social dimension. AASHE (2014) refers sustainability as a concept that embraces environmental security, intra-generational and inter-generational equity, economic betterment and social and environmental justice. Hence, it can be concluded that the whole aspect of sustainability consists of environment, social and economics which followed the description of sustainability by Elkington (2004) who refers sustainability as three bottom lines of 3P; Planet (Environment), Profit (Economic) and People (Social) as shown in Figure 1.0.

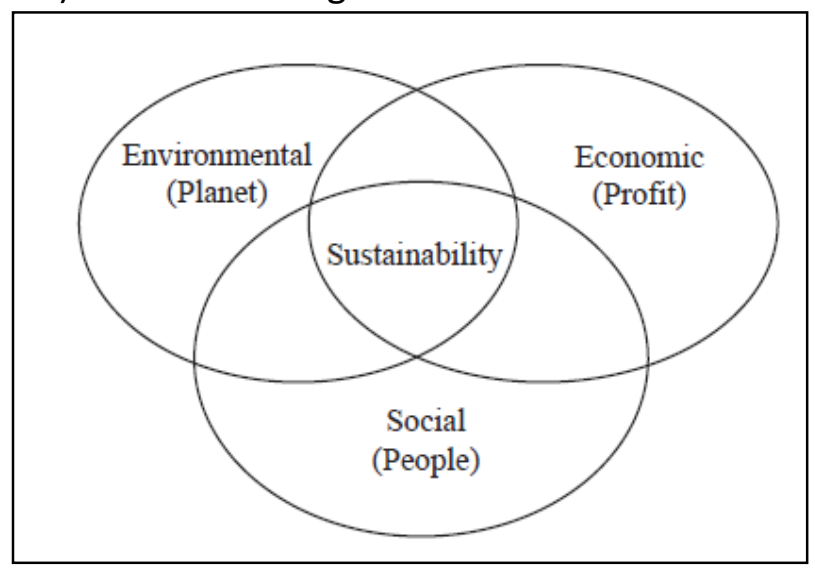


Figure 1 :- The three bottom lines of sustainability; Planet, Profit and People (Elkington, 2004).

Besides there are-many sustainability models that were developed and serve as guidance to $\mathrm{HEls}$ to practice and implement sustainability that proposed several themes or elements of sustainability in HEls such as Cortese (2003), Velazquez et. al (2005), Gomez et. al (2015) and many more. A study by Husaini and Jusoh (2017) on several models of sustainability in higher education institutions (HEIs) found that there are several themes or elements of sustainability involving $\mathrm{HEls}$ such as education, research, operation, campus engagement and reporting and assessment. A study conducted by Velazquez, (2005) describes sustainability activities in universities refers to environment, economics and social concerns and should minimize the negative environmental, economic, social and health effects generated in the use of their resources.

As conclusion, the concept of sustainability consists of three main aspects; environment, economics and social. There are also several elements of sustainability that should be emphasized among HEls which include the element of education, research, campus operation, community engagement and reporting. These are the factors that play a vital role in developing a sustainable university. Lozano et. al (2015) who reviews several literatures also highlights seven sustainability initiatives which are education, research, campus operation, outreach, on-campus experience, assessment and reporting and institutional framework. Thus, it is important of this study to review and analyse the indicators in sustainability assessment tools (SATs) and investigate the indicators allocation within the concept of sustainability and between the key elements of sustainability.

\section{Research Objective}

The objective of this paper is to review and analysis four sustainability assessment tools (SATs) for higher education institutions based on their percentage of elements and indicators.

\section{Research Questions}

1. What is the percentage of indicators in sustainability assessment tools (SATs) allocated in each aspects of sustainability; economy, environment and social?

2. What is the percentage of indicators in sustainability assessment tools (SATs) allocated in each of their elements?

\section{Literature Review}

\section{Sustainable Assessment Tools (SATs)}

This study is to review four existing sustainable assessment tools (SAT); Sustainability Tracking, Assessment and Rating System (STARS), Campus Sustainability Assessment Framework (CSAF), UI GreenMetric Ranking and Sustainable Assessment Questionnaire (SAQ). These four tools have been embedded by many HEls around the world includes from the west and the east. Some these SATs have their reputation and they developed their own ranking system. Each of SATs contain different of kind of elements and indicators to monitor and assess the sustainability performances among HEls. These four tools are described in detail in the following section.

\section{Sustainability Tracking, Assessment \& Rating System (STARS)}

STARS refer to Sustainability Tracking, Assessment \& Rating System which is coordinated under the association for the advancement of sustainability in higher education or known as AASHE. AASHE is an association of colleges and universities in United States and Canada and was founded in 2006 (AASHE, 2010). STARS is a sustainability self-reporting system that measure the progress of 
INTERNATIONAL JOURNAL OF ACADEMIC RESEARCH IN BUSINESS AND SOCIAL SCIENCES Vol. 8, No. 8, August 2018, E-ISSN: 2222-6990 @ 2018 HRMARS

sustainability for colleges and university. It is also known as one of the best comprehensive measuring tools for higher education institutions. There are four main areas of initiatives covers in STARS; education and research, operation, planning, administration and engagement (POE) and innovation (Yu-ti et. al, 2014). The overall framework of STARS is shown in Figure 2.0.

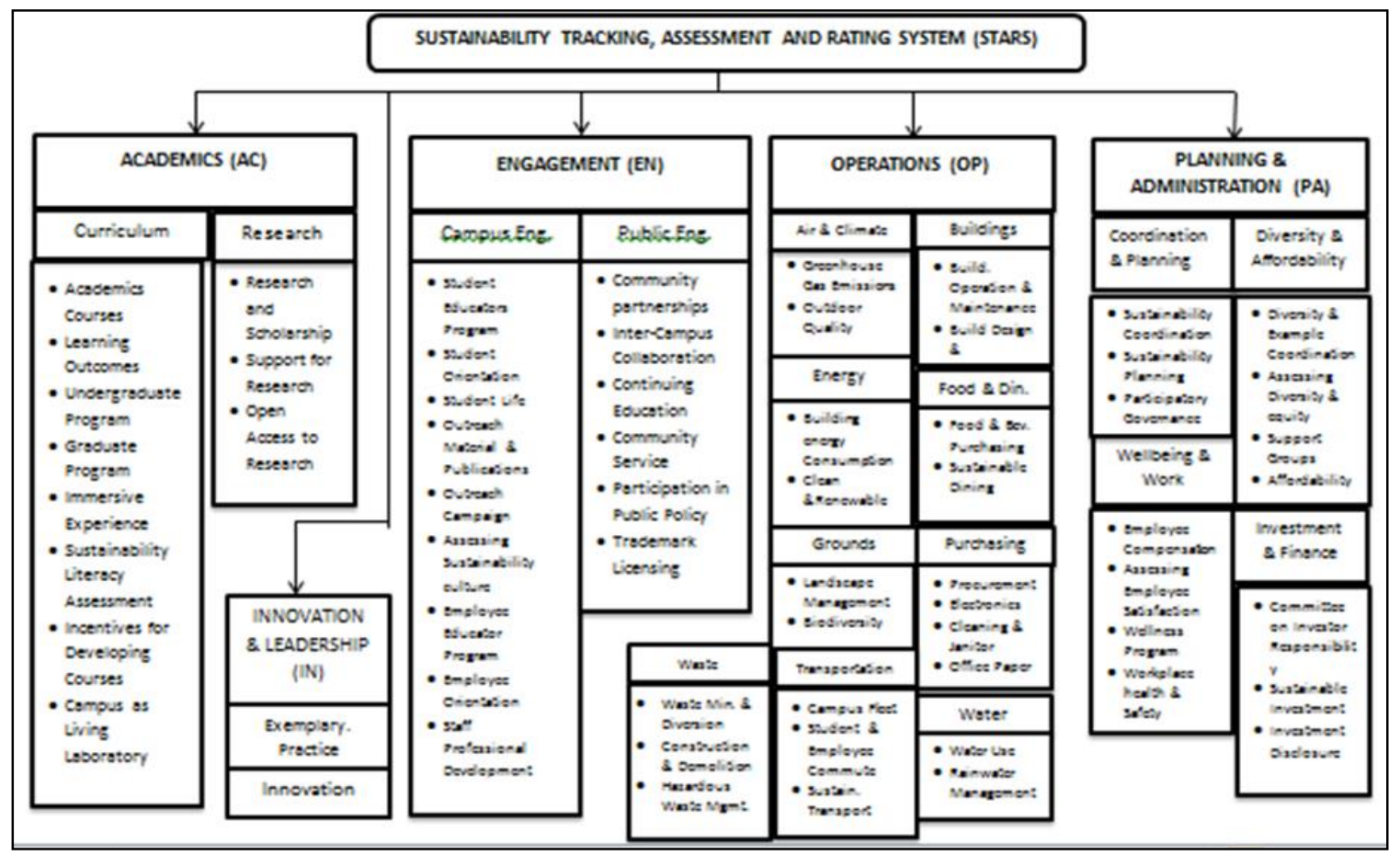

Figure 2:- Sustainability Tracking, Assessment \& Rating System (STARS) framework (AASHE, 2011)

\section{Campus Sustainability Assessment Framework (CASF)}

CASF refers to campus sustainability assessment framework which was developed by Lindsay Cole in her master thesis with the assistance of 15 other researchers in 2003. This framework is divided into two main area of assessment; ecological factor and people factor. The tool consists of ten elements of initiatives with a total 170 indicators. The ten main elements are divided into 1) Ecological;- land, air, water, energy and material and 2) People;- community, governance, knowledge, health and wellbeing and economy (Cole, 2003). The full framework of CASF is shown in Figure 3.0. 


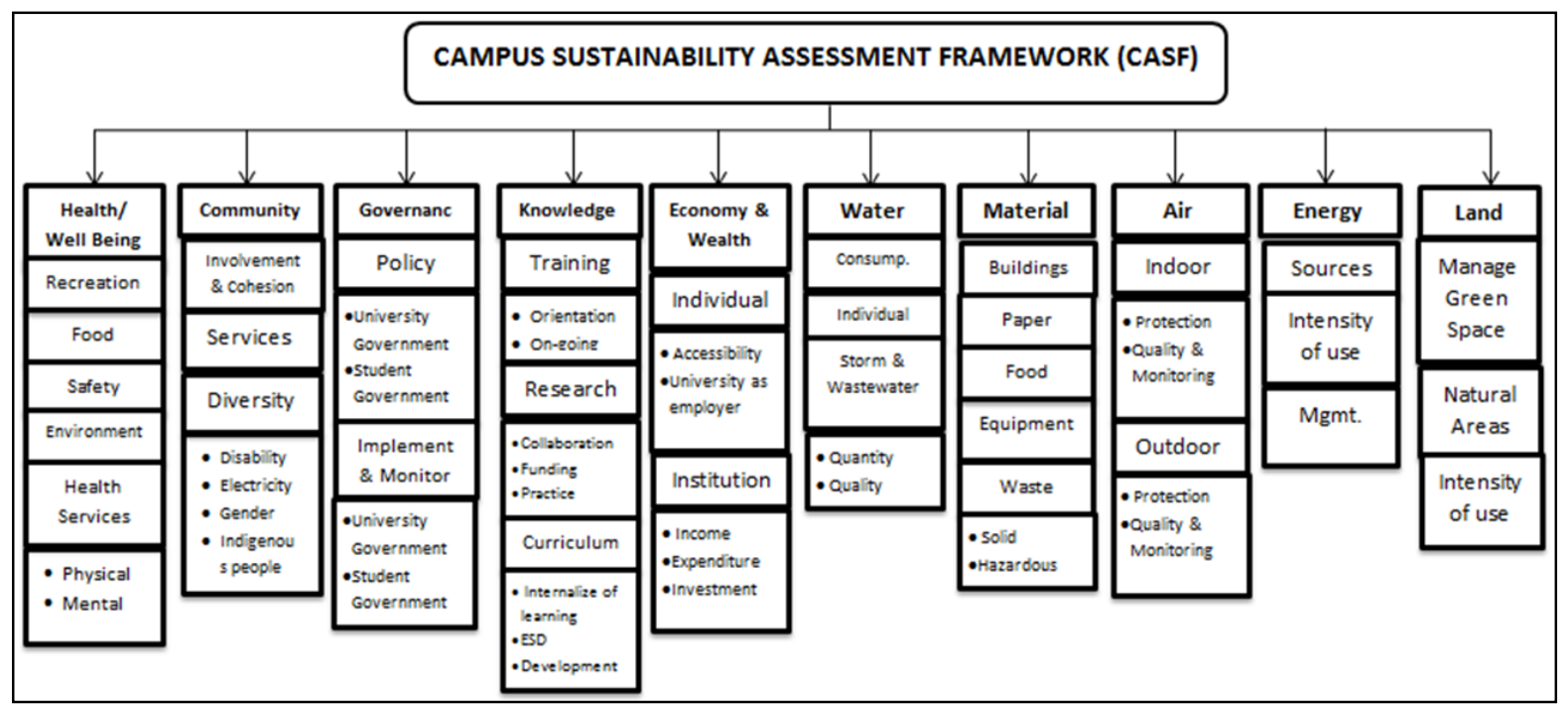

Figure 3 :- Campus Sustainability Assessment Framework (CASF) (Cole, 2003).

\section{UI GreenMetric Ranking}

UI GreenMetric Ranking is a sustainability ranking system developed by Universitas Indonesia which was designed to compare the commitment of universities to foster and promote green and sustainable activities within the campus. This ranking tool was launched in April 2010 and emphasized the aspect of global climate change, clean energy and water conservation, waste recycling and green transportation. There are six elements in UI GreenMetric Ranking and the each of the element is allocated with different percentage of indicators allocation. The six elements are: - (1) setting and infrastructure (15\%), (2) energy and climate change (21\%), (3) waste (18\%), (4) water (10\%), (5) transportation (18\%) and education (18\%) (UI GreenMetric, 2016). 
INTERNATIONAL JOURNAL OF ACADEMIC RESEARCH IN BUSINESS AND SOCIAL SCIENCES Vol. 8, No. 8, August 2018, E-ISSN: 2222-6990 @ 2018 HRMARS

The overall framework of UI GreenMetric ranking is shown in Figure 4.0.

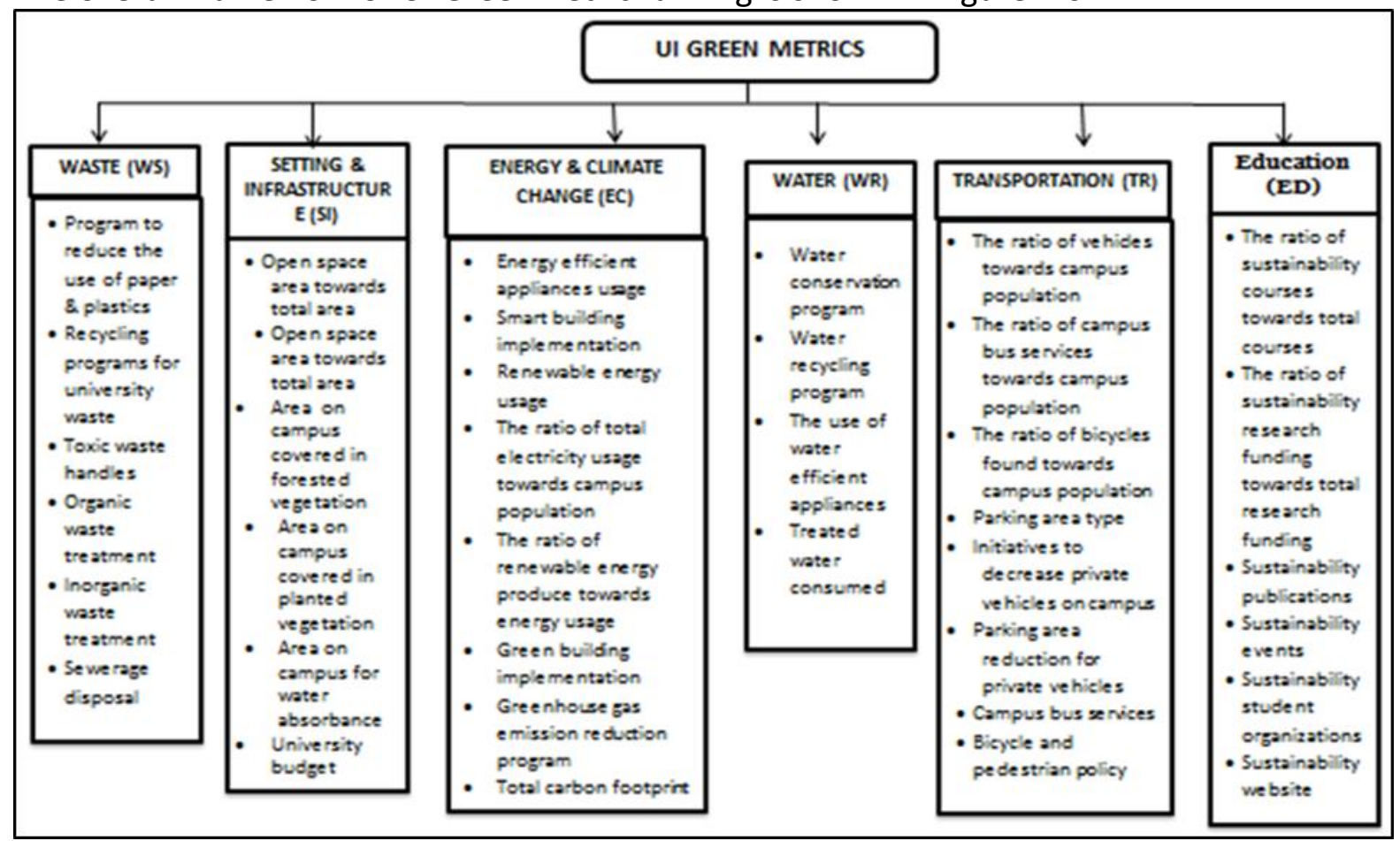

Figure 4:- UI GreenMetric 's framework (UI GreenMetric, 2016).

\section{Sustainable Assessment Questionnaire (SAQ)}

Sustainable Assessment Questionnaire (SAQ) refers to a sustainability survey tools that cover several initiatives of HEls. The questionaire measures seven elements of sustainability initiatives which includes curriculum, research and scholarship, operations, faculty and staff development and rewards, outreach and service, student opportunities and lastly administration, mission and planning (ULSF, 2009). This tool contains 25 survey questions and divides into seven main areas of sustainability in HEls. The overall framework of the SAQ indicators questions is shown in Figure 5.0. 
INTERNATIONAL JOURNAL OF ACADEMIC RESEARCH IN BUSINESS AND SOCIAL SCIENCES Vol. 8, No. 8, August 2018, E-ISSN: 2222-6990 @ 2018 HRMARS

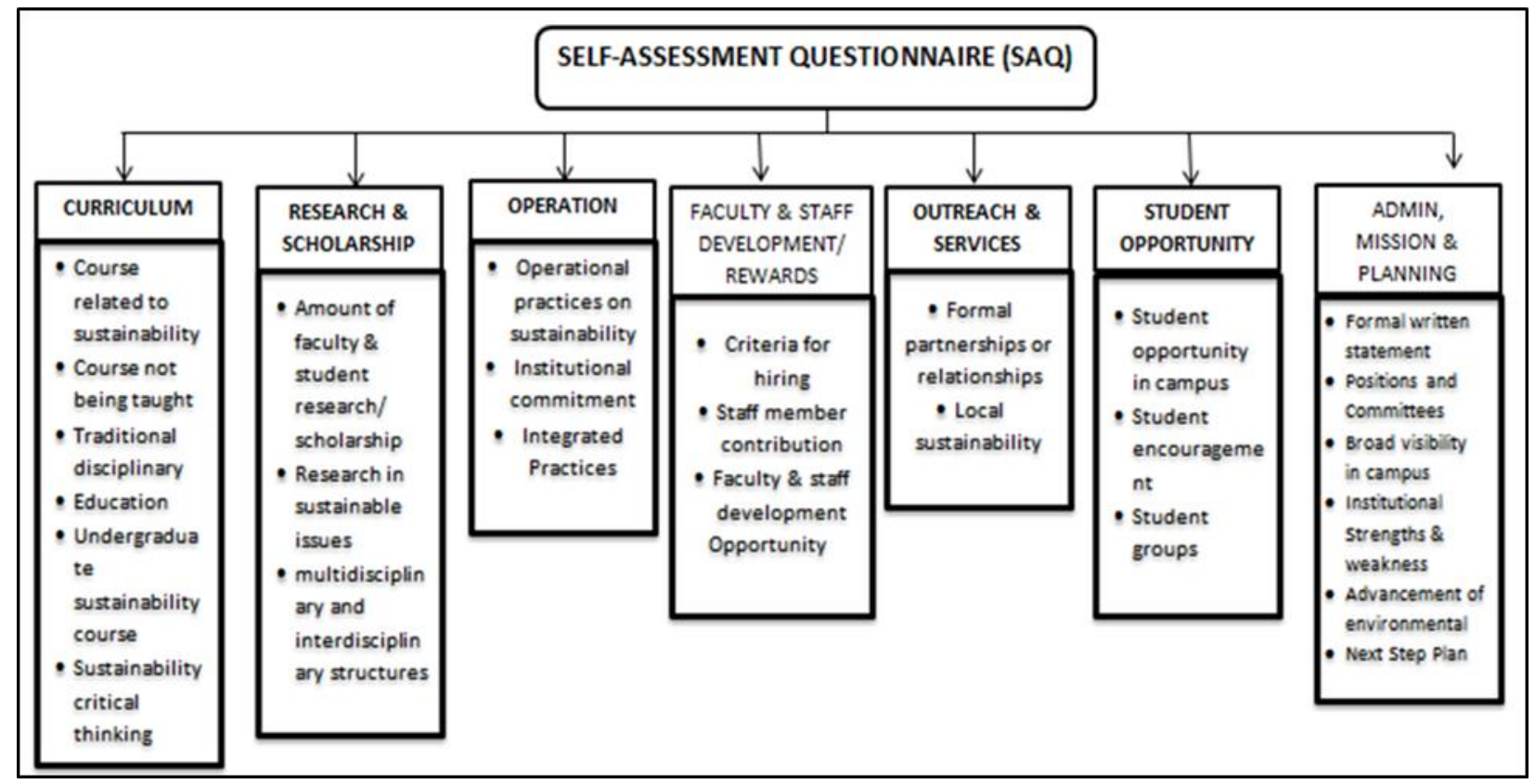

Figure 5.0:- Self- Assessment Questionnaire (SAQ) framework (ULSF, 2009)

Table 1.0 :- The summary of four SATs with the elements and number of indicators

\begin{tabular}{|c|c|c|c|}
\hline SATS & Elements \& Number of Indicators & & Total Indicators \\
\hline $\begin{array}{l}\text { Sustainability Tracking, } \\
\text { Assessment \& Rating System } \\
\text { (STARS) }\end{array}$ & $\begin{array}{l}\text { Academic - } 11 \text { indicators } \\
\text { indicators } \\
\text { Engagement - } 15 \text { indicators } \\
\text { indicators } \\
\text { Planning \& Administration - } 14 \text { indicators }\end{array}$ & $\begin{array}{l}\text { Operation - } 23 \\
\text { Innovation - } 2\end{array}$ & 65 indicators \\
\hline $\begin{array}{lr}\text { Campus } & \text { Sustainability } \\
\text { Assessment } & \text { Framework } \\
\text { (CASF) } & \end{array}$ & $\begin{array}{l}\text { Health \& Well-being - } 19 \text { indicators } \\
\text { indicators } \\
\text { Community - } 25 \text { indicators } \\
\text { indicators } \\
\text { Knowledge - } 21 \text { indicators } \\
\text { indicators } \\
\text { Governance - } 20 \text { indicators } \\
\text { indicators } \\
\text { Economy \& Wealth- } 18 \text { indicators } \\
\text { indicators }\end{array}$ & $\begin{array}{r}\text { Water }-11 \\
\text { Material - } 16 \\
\text { Air - } 14 \\
\text { Energy - } 12 \\
\text { Land - } 13\end{array}$ & 169 indicators \\
\hline UI GreenMetric Ranking & $\begin{array}{l}\text { Setting \& Infrastructure }-6 \text { indicators } \\
\text { Energy \& Climate Change }-8 \text { indicators } \\
\text { Waste }-6 \text { indicators } \\
\text { Water }-4 \text { indicators } \\
\text { Transportation }-8 \text { indicators } \\
\text { Education }-6 \text { indicators }\end{array}$ & & 38 indicators \\
\hline $\begin{array}{l}\text { Sustainable Assessment } \\
\text { Questionnaire (SAQ) }\end{array}$ & $\begin{array}{l}\text { Curriculum }-8 \text { indicators } \\
\text { Research \& Scholarship }-3 \text { indicators } \\
\text { Operation }-3 \text { indicators } \\
\text { Faculty \& Staff }-3 \text { indicators } \\
\text { Outreach }-2 \text { indicators } \\
\text { Student Opportunity }-3 \text { indicators } \\
\text { Administration, mission \& planning }-6 \text { indicators }\end{array}$ & & 28 indicators \\
\hline
\end{tabular}


INTERNATIONAL JOURNAL OF ACADEMIC RESEARCH IN BUSINESS AND SOCIAL SCIENCES

Vol. 8, No. 8, August 2018, E-ISSN: 2222-6990 @ 2018 HRMARS

\section{Analysis}

Two analyses were carried out. First analysis was to analyze the percentage of total indicators of each sustainability tool according to the three main aspect of sustainability; - social, environment and economic. Second analysis was to analyze the percentage of total indicators each sustainability tool in each of the elements covered within the tools.

The process of analysis was done by gathering all indicators between the four sustainability assessment tools. Then, the indicators will be sorted into two analyses. In the first analysis, all indicators were accumulated and divided into the three aspect of sustainability; - social, environment and economic. The classification of each indicator was determined based on its definition from two scholars. The definition of environment and economic aspect is based on Ekins, (2011) while the aspect of social refers to Valdes-Vasques,(2011). Then, the sum of each aspect were counted and presented into percentage.

In the second analysis, all indicators were accumulated and divided into the elements of sustainability. Each tool covers different type of elements and with different number of indicator. The sum of indicators of each element were counted and then presented into percentage.

\section{Result}

The results between the two analyses are shown in Table 2.0 and 3.0.

Analysis 1 :- The analysis of indicator's percentage within the aspect of sustainability.

Table 2.0:- The analysis of percentage indicator between the aspect of sustainability.

\begin{tabular}{|l|l|l|l|l|}
\hline \multirow{2}{*}{ No. } & \multirow{2}{*}{ Sustainable Assessment Tools } & \multicolumn{3}{|l|}{ Percentage of Sustainability's Indicators } \\
\cline { 3 - 5 } & & Social & Environment & Economic \\
\hline 1 & $\begin{array}{l}\text { Sustainability Tracking, Assessment } \\
\text { and Rating System (STARS) }\end{array}$ & $61.9 \%(39)$ & $22.2 \%(14)$ & $15.9 \%(10)$ \\
\hline 2 & $\begin{array}{l}\text { Campus Sustainability Assessment } \\
\text { Framework (CSAF) }\end{array}$ & $45.1 \%(79)$ & $40.6 \%(71)$ & $14.3 \%(25)$ \\
\hline 3 & $\begin{array}{l}\text { Sustainability Assessment } \\
\text { Questionnaire (SAQ) }\end{array}$ & $48.6 \%(17)$ & $37.1 \%(13)$ & $14.3 \%(5)$ \\
\hline 4 & Ul Green Metric Ranking & $47.4 \%(18)$ & $47.4 \%(18)$ & $5.2 \%(2)$ \\
\hline \multicolumn{2}{|l|}{ Average Percentage } & $50.75 \%$ & $36.83 \%$ & $10.5 \%$ \\
\hline
\end{tabular}


INTERNATIONAL JOURNAL OF ACADEMIC RESEARCH IN BUSINESS AND SOCIAL SCIENCES

Vol. 8, No. 8, August 2018, E-ISSN: 2222-6990 C 2018 HRMARS

Analysis 2 :- The analysis of indicator's percentage within the elements of sustainability.

Table 3.0:- The analysis of indicators among the key elements of sustainability.

\begin{tabular}{|c|c|c|c|c|c|c|c|}
\hline \multicolumn{2}{|l|}{ SAQ } & \multicolumn{2}{|l|}{ CASF } & \multicolumn{2}{|l|}{ STARS } & \multicolumn{2}{|l|}{ UI GreenMetric } \\
\hline Element & $\%$ & Element & $\%$ & Element & $\%$ & Element & $\%$ \\
\hline Curriculum & 20 & $\begin{array}{l}\text { Health \& Well } \\
\text { Being }\end{array}$ & 11 & Academics & 17 & $\begin{array}{l}\text { Setting \& } \\
\text { Infrastructure }\end{array}$ & 16 \\
\hline $\begin{array}{l}\text { Research \& } \\
\text { Scholarship }\end{array}$ & 12 & Community & 15 & Engagement & 23 & $\begin{array}{l}\text { Energy } \quad \& \\
\text { Climate }\end{array}$ & 20 \\
\hline Operation & 12 & Knowledge & 12 & Operations & 35 & Waste & 16 \\
\hline Faculty & 12 & Governance & 12 & $\begin{array}{l}\text { Planning \& } \\
\text { Administration }\end{array}$ & 22 & Water & 11 \\
\hline Outreach & 8 & $\begin{array}{l}\text { Economy/ } \\
\text { Wealth }\end{array}$ & 11 & $\begin{array}{l}\text { Innovation \& } \\
\text { Leadership }\end{array}$ & 3 & Transport & 21 \\
\hline Student & 12 & Water & 7 & & & Education & 16 \\
\hline Administration & 24 & $\begin{array}{l}\text { Material } \\
\text { Air } \\
\text { Energy } \\
\text { Land }\end{array}$ & $\begin{array}{l}9 \\
8 \\
7 \\
8\end{array}$ & & & & \\
\hline
\end{tabular}

STARS

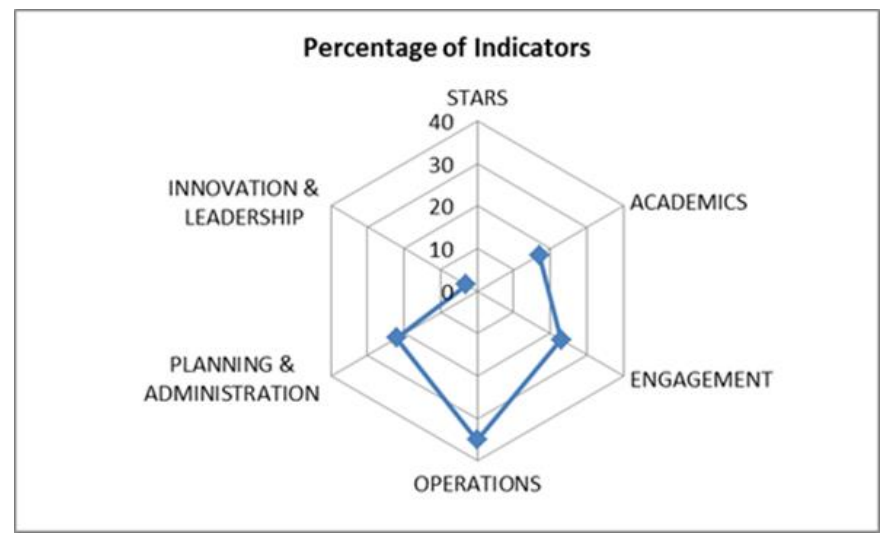

Figure 6.0 :- The indicators analysis between elements in STARS. 
INTERNATIONAL JOURNAL OF ACADEMIC RESEARCH IN BUSINESS AND SOCIAL SCIENCES Vol. 8, No. 8, August 2018, E-ISSN: 2222-6990 @ 2018 HRMARS

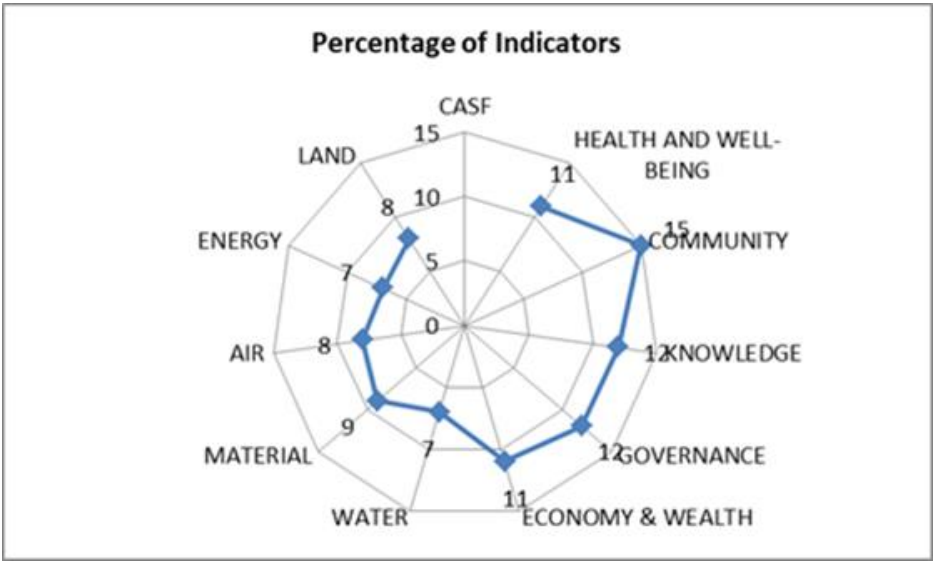

Figure 7.0 :- The indicators analysis between elements in CASF.

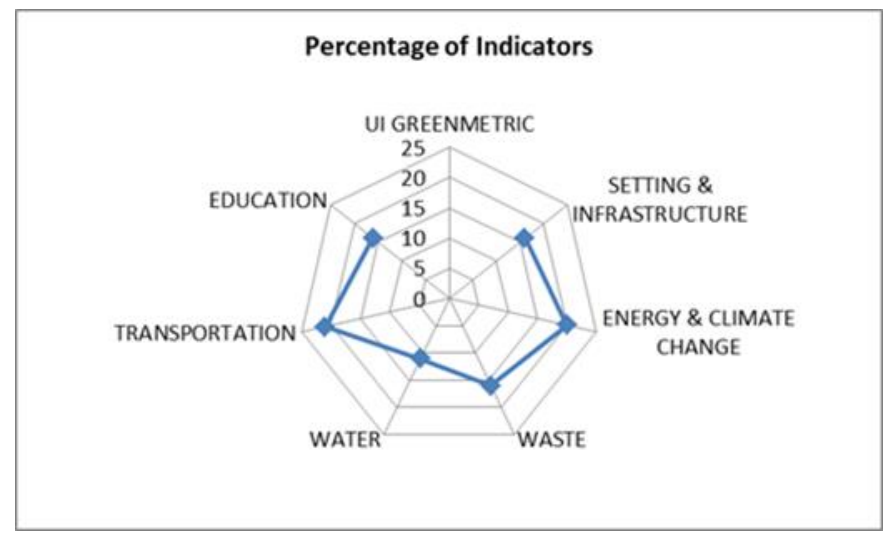

Figure 8.0 :- The indicators analysis between elements in UI GreenMetric.

\section{SAQ}

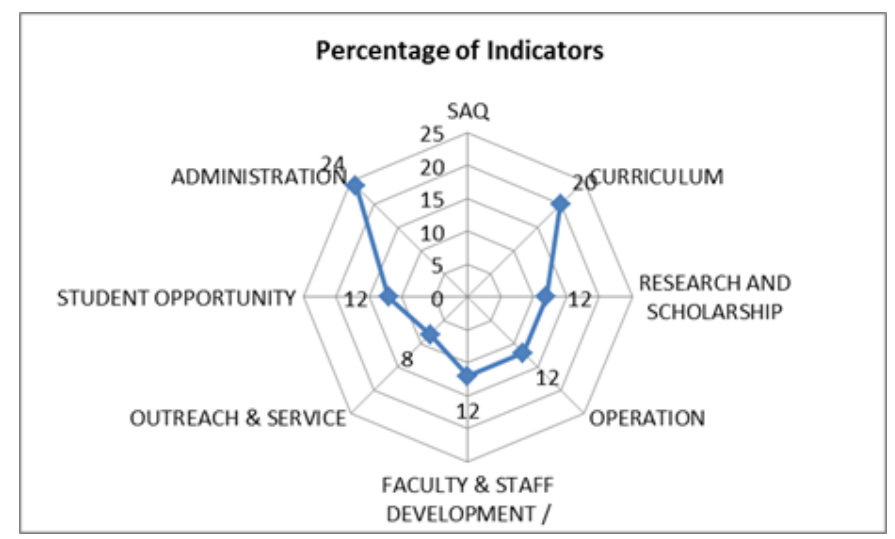

Figure 9 :- The indicators analysis between elements in SAQ. 
INTERNATIONAL JOURNAL OF ACADEMIC RESEARCH IN BUSINESS AND SOCIAL SCIENCES

Vol. 8, No. 8, August 2018, E-ISSN: 2222-6990 @ 2018 HRMARS

\section{Discussion}

The results from Analysis 1 indicate that there is a significant imbalance proportion of indicators according to three main aspects of sustainability. STARS has more indicators in social (61.9\%) but less indicators in economic (15.9\%). CASF is also has more indicators in social (45.1\%) and environment (40.6\%). However, it is still less in economic (14.3\%). The findings are similar with UI GreenMetric and SAQ which contain more indicators in social and environment compare to economic. UI GreenMetric Ranking tool has less than 10\% percentage indicators (5.2\%) in economic while the SAQ covers only $14.3 \%$ of indicators in economic.

In analysis 2, result shows that each SAT comes out with different kind of indicator allocation in each element of the tools. In STARS, the percentage of indicators is more in the element of operations (35\%) compare to engagement (23\%) and planning and administration (22\%). In CASF, the allocation of indicators is average between the elements contained in ecological (39\%) and people (61\%). In UI GreenMetric, the proportion percentage of indicators in each element is slightly equal and same with transportation (21\%), energy and climate (20\%), setting and infrastructure (16\%), waste (16\%), education (16\%) and water (11\%). In SAQ, the tool is more focused on the element of administration (24\%) and curriculum (20\%). Other elements are also quite average and equal such as research and scholarship (12\%), operation (12\%), faculty and staff development (12\%), student opportunity (12\%) and outreach and service (8\%).

\section{Conclusion}

Based on analysis 1, it can be concluded that there is significant imbalance of indicator proportion between the three aspects of sustainability. Result shows that most of the SATs allocate more of their indicators into the aspect of social and environment. However, in the aspect of economic, the allocation percentage is quite less and low.

Based on analysis 2, it can be concluded that there is a significant imbalance between the proportions of each element in the SATs. Most of SATs allocate their indicators based on the element that they consider as important and crucial. For example, in STARS, it allocates many indicators into the element of operation while SAQ emphasized more on the element of administration and curriculum.

\section{Recommendation}

There are several recommendations that can be made based on the findings. First, the indicators among the four SATs should be improved and restructured. The allocation of indicators must be balanced within the three main aspects of sustainability and the elements within the SATs. Second, there is a need for further research on several other SATs used by many higher education institutions around the world such as College Sustainability Report Card, Good Company's Sustainable Pathways Toolkit, National Wildlife Federation's State of the Campus Environment, Campus Ecology and many more. Third, further research also can be done in reviewing and comparing the elements contained in the SATs with the elements of sustainability in the literature. There are several scholars who did the analysis of declaration and literatures. Wright (2003) and Lozano et.al (2013) outline ten initiatives of sustainability from declaration which are curriculum, research, operation, outreach and collaboration, university collaboration, assessment, trans disciplinary, institutional framework, SD through campus experience and educate the educators. 
INTERNATIONAL JOURNAL OF ACADEMIC RESEARCH IN BUSINESS AND SOCIAL SCIENCES

Vol. 8, No. 8, August 2018, E-ISSN: 2222-6990 @ 2018 HRMARS

\section{Acknowledgement}

Special acknowledgement to Associate Prof Dr. Ahmad Bin Jusoh and Dr. Mohamad Shah Bin Kassim

\section{Corresponding Author}

Mohd Zamri Husaini, zamstings83@yahoo.com.my

Azman Hashim International Business School

Universiti Teknologi Malaysia

81310 Johor Bahru, Johor, Malaysia.

\section{References}

AASHE (2014), Association for the Advancement of Sustainability in Higher Education Stars technical manual: version 2, available at: www.aashe.org/files/documents/STARS/2.0/ stars_2.0_technical_manual_-_administrative_update_two.pdf (accessed 4 May 2015).

AASHE (2010). Sustainability Tracking, Assessment \& Rating System: Version 1.0 Technical Manual, Association for the Advancement of Sustainability in Higher Education, Lexington, KY.

Berzosa, A., M. O. Bernaldo, G. Fernandez-Sanchez (2017) Sustainability Assessment Tools for Higher Education : An Emperical Comparative Analysis. Journal of Cleaner Production, 161(2017), 812-820.

Brundtland Report (1987, December). Report on the World Commission on Environment and Development. United Nations General Assembly Resolution 42/187.

Cole L. (2003). Assessing Sustainability on Canadian University Campuses: Development of a Campus Sustainability Assessment Framework. B.Sc dissertation. Canada: Royal Roads University.

Cortese A.D (2003). The critical role of higher education in creating a sustainable future, Planning for higher education, March-May 2003.

Ekins, P. (2011). Environmental sustainability: From environmental valuation to the sustainability gap. Progress in Physical Geography, 35, 629-651.

Elkington, J., (2004). Enter the triple bottom line. In: Henriques, A., Richardson, J. (Eds.), The Triple Bottom Line: Does it All Add up. Earthscan, London, UK, 1-16.

Fischer, D., Jenssen, S. \& Tappeser, V. (2015). Getting an empirical hold of the sustainable university: a comparative analysis of evaluation frameworks across 12 contemporary sustainability assessment tools. Assessment \& Evaluation in Higher Education, 40(6), 785-800.

Gomez F. U., Cesar S.N., Solange R.L, \& Vartan I.M. (2015). Adaptable model for assessing sustainability in higher education, Journal of Cleaner Production 107 (2015) 475-486.

Husaini M.Z \& Jusoh A. (2017). The Review of Sustainability Model and Indicators for Higher Education Institutions in Malaysia. International Journal of Academic Research in Business and Social Sciences 2017, 7, 11

Lozano R. (2009) Envisioning sustainability three-dimensionally, Working paper series No. 39. Centre for Business Relationships, Accountability, Sustainability and Society (BRASS). Available online: http://works.bepress.com/rodrigo_lozano/5; 2007 [15 May 2009].

Lozano, R., Lukman, R., Lozano, F.J., Huisingh, D., \& Lambrechts, W.,(2013). Declarations for sustainability in higher education: becoming better leaders, through addressing the university system. Jurnal of Clean. Production. 48, 10-19.

Lozano, R., Ceulemans, K., Alonso-Almeida, M., Huisingh, D., Lozano, F.J., Waas, T., Lambrechts, W., Lukman, R. \& Huge, J. (2015). A review of commitment and 
INTERNATIONAL JOURNAL OF ACADEMIC RESEARCH IN BUSINESS AND SOCIAL SCIENCES

Vol. 8, No. 8, August 2018, E-ISSN: 2222-6990 C 2018 HRMARS

implementation of sustainable development in higher education: results from a worldwide survey. Journal of Cleaner Production, 108, 1-18.

Nixon, A. (2002). Improving the Campus Sustainability Assessment Process. Undergraduate Honors Thesis, Western Michigan University.

UNESCO. (1984). Activities of the UNESCO-UNEP International Environmental Education Programm (1975-1983). United Nations Educational, Scientific and Cultural Organization, Paris.

Shriberg, M. ( 2002). Institutional Assessment Tools for Sustainability in Higher Education:

Strengths, Weaknesses, and Implications for Practice and Theory, International Journal of Sustainability in Higher Education, 3 (3), 254-70.

UI GreenMetric (2016). http://greenmetric.ui.ac.id/wp-content/uploads/2015/07/Brosur-UIGreenMetric-2016.pdf, Copyright (c) 2016 Universitas Indonesia

University Leaders for a Sustainable Future (2009). Sustainability Assessment Questionnaire (SAQ) for Colleges and Universities, University Leaders for a Sustainable Future. Available from http://www.ulsf.org/pdf/SAQforHigherEd09.pdf

Valdes-Vasques, R. (2011). Social sustainability considerations during planning and design: A framework of processes for construction projects. ProQuest.

Velazquez L, Nora Munguia, Alberto Platt, and Jorge Taddei (2005), Sustainable university: what can be the matter?, Industrial Engineering Department, University of Sonora (Mexico).

Wright, J. (2003). Introducing sustainability into the architecture curriculum in the United States. International Journal of Sustainability in Higher Education, 4, 100-105.

Yarime, M. \&. The issues and methodologies in sustainability assessment tools for higher education institutions: a review of recent trends and future. 